\title{
Giant reed (Arundo donax L.) from ornamental plant to dedicated bioenergy species: review of economic prospects of biomass production and utilization
}

\author{
Antal, G. \\ University of Debrecen, Faculty of Economics and Business, Institute of Sectoral Economics and Methodology, 138. Böszörményi str., \\ Debrecen, H-4032, Hungary \\ Author for corresponding: antal.gabriella@econ.unideb.hu
}

\begin{abstract}
Summary: Giant reed (Arundo donax L.) is a perennial, herbaceous grass, it has been spread all over the world from continent to tropical conditions by human activities. In continental climate, especially Hungary, it has been considered as ornamental species, due to its decorative appearance, striped variants' colour of leaves, long growing season and low maintenance requirements. It does not produced viable seeds, so it can be propagated vegetative ways by rhizomes or stem cuttings and by in vitro biotechnology methods. Because of its growth habits and good adaptation capability, it has been considered invasive weed primarily in coastal regions in warmer climate areas. In the previous century, giant reed produced for paper/cellulose/viscose production, woodwind musical instruments, stakes for plants or fishing rods etc. Over the last few decades, it has been produced for bioenergy purposes (bioethanol, biogas, direct combustion) or utilize as chemical basic compounds or construction materials. It has been considered a dedicated promising biomass crops thanks to high biomass production, high energy balance of cultivation and adaptability of different kind of soils and conditions. The objective of the present paper is to overview the most significance literature data on giant reed production and utilization, compare to own experimental data and economic calculations and to determine some critical factors, advantages and disadvantages of giant reed production compare to other biomass species.
\end{abstract}

Antal, G. (2018): Giant reed (Arundo donax L.) from ornamental plant to dedicated bioenergy species: review of economic prospects of biomass production and utilization. International Journal of Horticultural Science 24(1-2): 39-46. https://doi.org/10.31421/IJHS/24/1-2./1545

Key words: giant reed, biomass production, biomass utilization, economic benefits

\section{Introduction}

The energy consumption of the global population is still depends on fossil fuels, in spite of the rapidly increasing role of renewable energies, environmental problems and climate policies. The biomass is the greatest renewable resources, with almost $73 \%$ share of global renewable energy supply (IEA, 2017). The annual rate of biomass utilization is less than other renewable resources (especially sun or wind), so it should be used the biological resources more effectively to ensure food and energy demands of a growing population (WBA, 2017).

The world is already moving towards to the "bio-based society", confirmed many practical examples (optimized production system with less waste generation, recycling, biobased production instead of fossil-based products, protein-rich animal feed, healthy food ingredients, circulation of nutrients to the soil etc.). However, globally the biomass resources utilize as heat or electricity production, it has been produced biofuels for transportation, bioplastic and biobased chemicals etc. The most optimized way of using biomass to utilize its nutritional values, structural building blocks, not only energy contents. Cellulose, hemicellulose, lignin and leaf proteins are valuable components of green biomass to produce higher value added new products such as feed and food ingredients, medicine and health promoters (Lange \& Lindeman, 2016). Nowadays, the soybean is one of the most important protein sources of animal husbandry, but by fractionation of green biomass leaves can be produce also valuable leaf protein concentrate. The production of fractioned green leaf is not a new concept, because in the beginning of last century, Karoly Ereky, the "father" of term biotechnology, has already used the fractional technique to produce fodder to feed. The fractioned green biomass techniques were developed over the previous decades, but its application did not spread widely (Popp \& Fári, 2016). Nevertheless, there are many biological, ecological, economical and technological problem with biomass plant production and utilization. One of the most promising opportunities to produce perennial species in marginal lands. Dedicated plants with large root system can restore the quality of soils and result more environmentally friendly production, because of less soil cultivation intervention contribute the reduction of $\mathrm{CO}_{2}$ emission (Fári et al., 2014).

University of Debrecen has been carrying out biological, genetical, agronomic and biotechnological researches on perennial, primarily herbaceous plant species suitable for bioindustrial processing that can be grown on marginal areas. The objective of the present paper is to overview the most significance literature data on giant reed production and utilization, compare with own experimental data and economic calculations and other biomass species' data. 


\section{Materials and methods}

Within the framework of the University of South Carolina (USA) and the University of Debrecen, MÉK, Department of Plant Biotechnology (Hungary) joint research program, has been developed in vitro propagation techniques of dedicated perennial species, giant reed (Arundo donax L.) and miscanthus (Miscanthus $x$ gigantheus) based on methods of Márton \& Czakó (2002a, b, 2007a, b). From in vitro propagation of two different giant reed ecotypes uses somatic embryogenesis were propagated and acclimatized seedlings were planted in the Experimental Garden of Future Biomass Crops at University of Debrecen. Resulting of joint researches, from 2010 in several places in Hungary and other countries in the world (USA, Italy, Spain, China, Romania, Ukraine and Slovakia) has been started to establish biotechnologically propagated giant reed plantations. I have been collecting production and utilization data of giant reed plantation in Hungary from 2013 until 2018 (based on plantations of University of Debrecen), used for costbenefit analyses of giant reed production. I compared the results with significant literature data to introduce and overview the most relevant properties of giant reed in aspects of production and different utilization methods by economical, ecological and biological advantages and disadvantages of giant reed compare with other biomass species. In case of higher value added products from giant reed and other species from Experimental Garden of Future Biomass Crops at University of Debrecen could produce leaf protein concentrate (LPC) based on Ereky's process (Fári \& Popp, 2016) and combined with the coagulation technique was related to patent application. Department of Agricultural Botany, Plant Physiology and Plant Biotechnology, MÉK, University of Debrecen were measured physical and chemical parameters from the LPCs and the by-products (brown juice, green fiber) from different species supported by the GINOP-2.2.1-15-201700051 project, is co-financed by the European Union and the European Regional Development Fund. Based on these results and data, I evaluated the efficiency and perspectives of LPC production and available protein content per unit from giant reed compared to a dedicated forage crop, alfalfa (Medicago sativa L.).

\section{Results}

\section{Importance of giant reed researches}

The growing importance and interest of giant reed can be obviously characterized by literature databases. Based on the Google Scholar database, the total number of publications is over 17400 (Until 12.11.2017), from which in 1340 paper's title contain the plant's scientific name (Arundo donax or giant reed). Over the last 50 years, the number of publications about giant reed has been increasing, between 1997 and 2001 it almost doubled, which was typical of the later periods (Figure 1). Over the past 10 years, more than 13000 scientific papers were published which are related to the plant, and annually, almost 100 publications appeared with giant reed or Arundo donax names in the title of publications. In those papers, the term of "biomass" and "energy" 5 600, the "biorefinery" 1080 , the "biofuel" 2620 , the "biogas" 1270 , the "musical" 612, the "invasive" 4040 and the "phytoremediation" 956 pieces of publication contained. It is interesting that the word "propagation" and "in vitro" same 1560 publications can be found in Google Scholar's search base (Until 12.11.2017) (Figure 1).

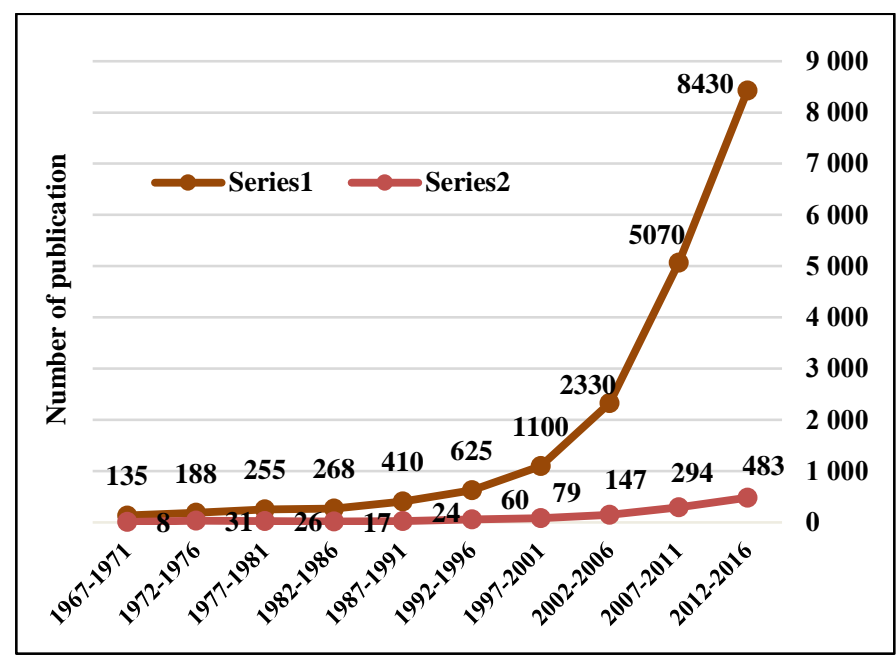

Figure 1: Number of publications related to "giant reed" or "Arundo donax" in Google Scholar's database (between 1967-2016)

Source: author's composition based on a Google Scholar database. Series 1) Number of publications containing the plant's scientific name. Series 2) Number of publications containing the plant's scientific name in the title.

\section{Chemical composition and valuable properties from view of production}

The physical and chemical composition of giant reed was reported in several publications, such as a lignocellulose plant. The ratio of cellulose and hemicellulose is approximately 55$60 \%$ with higher cellulose content (30-39\%), and the amount of lignin (20-24\%) and ash (4-6\%) are also relatively high (Corno et al., 2014). Some authors (Neto et al., 1997; Shatalov \& Pereira, 2002a,b; Ververis et al., 2004) determined the chemical composition of the various segments of the plant, which shows that the chemical content of internodium, nodes and leaf are diverse (Figure 2). The internodium contains average $34.61 \%$ cellulose, $26.58 \%$ hemicellulose, $19.58 \%$ lignin and $4.38 \%$ ash. The percentage of cellulose content of internodium with nodes is less $(30.80 \%)$, hemicellulose content is higher $(28.62 \%)$, but the lignin $(18.97 \%)$ and ash content $(4.38 \%)$ is almost same than internodium. According to Neto et al. (1997), the leaves of plant contain $35.1 \%$ cellulose, $25.60 \%$ hemicellulose, $16.80 \%$ lignin and $5.80 \%$ ash (Figure 2 ).

It also increases the plant's biological value that it is able to adapt to different type of soils, marginal, periodically flooded or saline territories (Pilu et al., 2012). Numerous authors is reported that giant reed can accumulate heavy metals (cadmium, nickel, lead, chromium, arsenic, mercury, copper etc.) (Mlinarics et al., 2009; Alshaal et al., 2013; 2014; Elhawat et al., 2014; 2015), because of its expanded root system and vigorous ground biomass. Therefore, as phytoremediation plants can restore the soil ecosystem (Alshaal et al., 2013; 2015) from sewage and from different pollutants (Simon et al., 2012; Elhawat et al., 2013a; 2015). Giant reed can grow on red mud, high $\mathrm{pH}$ or EC, heavy metal polluted soils (Alshaal, 2013). In addition Domokos-Szabolcsy et al. (2014) and El-Ramady et al. (2015) reported its tolerance of different selenium forms and according to Williams et al. (2008) and Elhawat et al. (2013b) giant reed can be adapt to salty soil. 


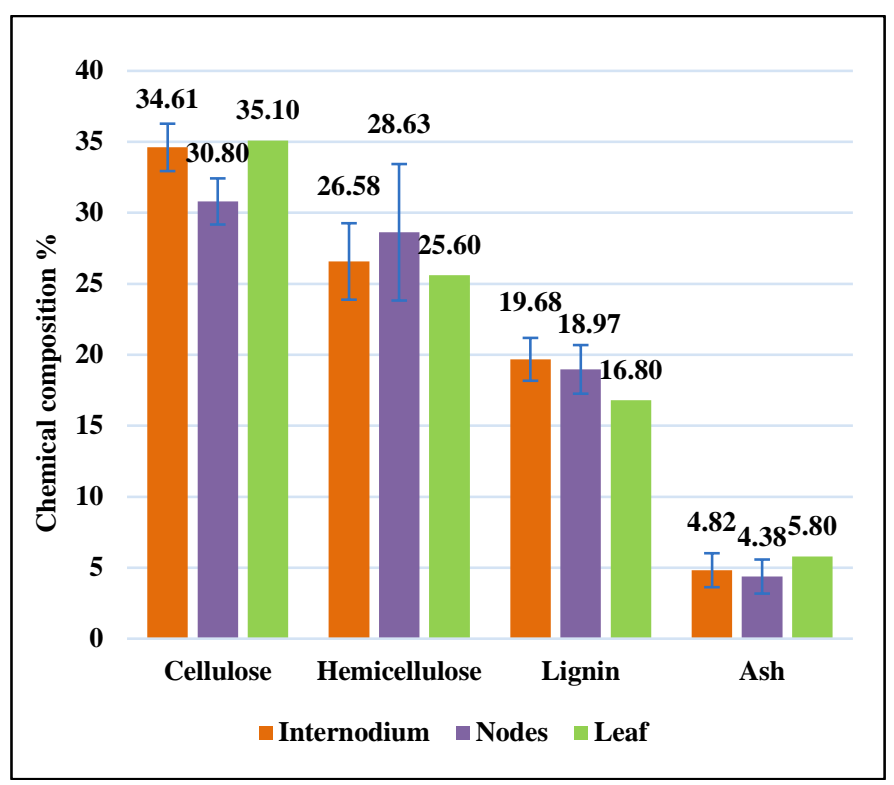

Figure 2. Chemical composition of different segments of giant reed

Source: Neto et al. (1997); Shatalov \& Pereira (2002a,b); Ververis et al. (2004)

\section{Biomass yields and production cost depending on cultivation elements}

Giant reed can produce different biomass yield in different climate and cultivation conditions. Based on numerous significant reports, the biomass yield of multi-annual giant reed plantation can reach 30 tons dry matter per hectare $(\mathrm{t} \mathrm{DM} \mathrm{ha-1)}$ per year in Mediterranean environment (Figure 3). The annual quality and quantity of biomass production are influenced by a lot of factors (microclimate, soil, agronomic techniques, harvest time and method etc.), therefore biomass yields show large standard deviations. The average values of the Figure 3 represent warmer condition's data than continental climate, such as Hungary.

Contrary to the large number of foreign literatures, there are very few Hungarian publications which are dealing with the properties and cultivation of giant reed, and they are largely referring to the results of foreign sources. Hungarian literatures estimated an average $20 \mathrm{t} \mathrm{DM} \mathrm{ha}^{-1}$ in Hungary with annual precipitation of $650-800 \mathrm{~mm}$. According to Fogarassy (2001), the annual biomass yield of the plant is between 20-30 t DM $\mathrm{ha}^{-1}$ on average soils without irrigation. As reported Gyulai (2009) and Csete (2008a, b, c) biomass production of giant reed can be achieved $20 \mathrm{t} \mathrm{DM} \mathrm{ha}^{-1}$, but with adequate irrigation and fertilization can be reached $35 \mathrm{t} \mathrm{DM} \mathrm{ha}^{-1}$.

Based on the field experiment in Debrecen, giant reed ecotype from the subtropical climate could produce average $16.37 \mathrm{t} \mathrm{DM} \mathrm{ha}^{-1}$ under six cultivation year, on calcareous chernozem soil without irrigation and fertilization, because of the frost damage in 2012. While ecotype from Hungary could produce average $18.05 \mathrm{t} \mathrm{DM} \mathrm{ha}^{-1}$ at the end of winter harvest time under six cultivation year. It can be concluded that in $1 \times 1$ meter plant spacing (10 000 plants per hectare) is enough to establish giant reed plantation. Based on our field experiment, in more dense plant spacing (13 334 or 20000 plant per hectare) the biomass productions did not increase, but the establishment costs are greatly influenced (Antal, 2018).

In experiments of Cavallaro et al. (2014), in the first year with previous autumn establishment $12.1 \mathrm{t} \mathrm{DM} \mathrm{ha}^{-1}$, with the early spring establishment $20 \mathrm{t} \mathrm{DM} \mathrm{ha}^{-1}$ biomass produced in

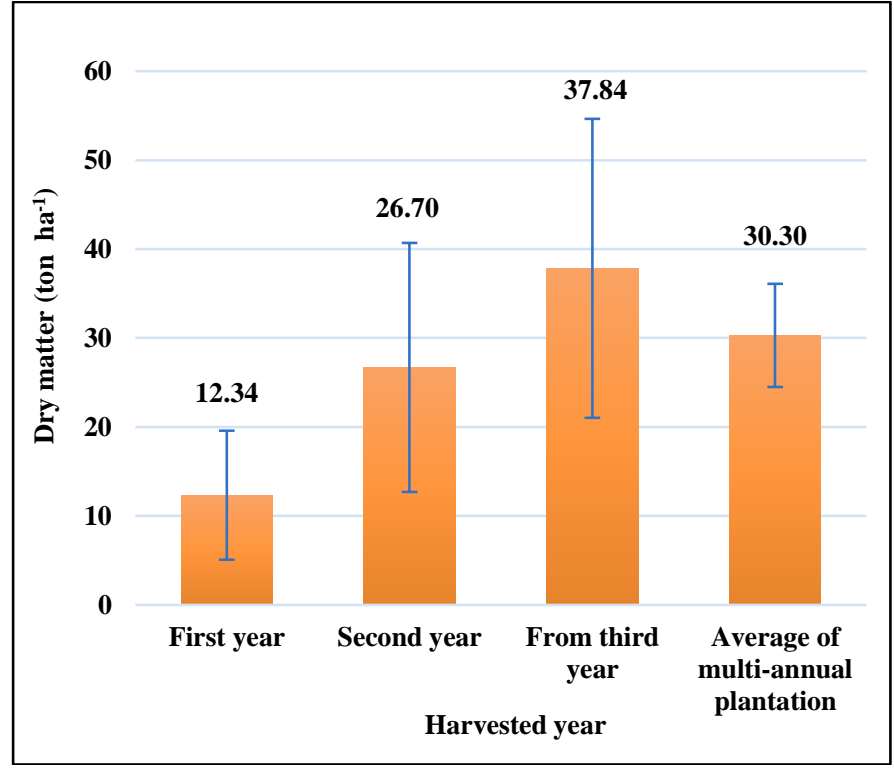

Figure 3: Biomass yield of giant reed plantations in the Mediterranean environment

Source: Christou et al. (2003); Angelini et al. (2005; 2009); Cosentino et al. (2006; 2008); Mantineo et al. (2009); Ceotto \& Di Candilo (2010); Roncucci et al. (2012); Nassi o Di Nasso et al. (2011a, b, 2013a, b); Ceotto et al. (2015); Dragoni et al. $(2015,2016)$

Northern Italy. The average biomass yield of micropropagated derived giant reed plantation in a warmer climate in the 3-4 years could produce approximately $22 \mathrm{t} \mathrm{DM} \mathrm{ha}^{-1}$ (Roncucci et al., 2012; Nassi o Di Nasso et al., 2013a; 2013b; Corno et al., 2014), which above 4-6 t DM yields than measured in Debrecen (Hungary).

The production of perennial plants differs from annual arable plant cultivation. In the viewpoint of economic calculation, the life cycle of perennial plant production lasts from the propagation of propagules until the elimination of the plantation. Based on own research activity and literature data, giant reed production can be feasible in continental climates, also in Hungary. Harvest time is depending on the utilization method, but for the sustainable, low cost cultivation in a continental climate, the end of the winter season could be the optimal harvest time of giant reed (Antal, 2018). During estimated 15-20 years of giant reed production, the cost of establishment, the price of propagules is one of the most expensive direct cost besides the harvest and transportation costs (Pilu et al., 2012). Calculation of Pilu et al. (2012), in North Italy, the annual cost of cultivation without irrigation (apart from the first year) reaching at least 700 euro ha $^{-1}$ (can be 1000 euro $\mathrm{ha}^{-1}$ ), if the propagules are derived from the rhizomes ( 0,5 euro/propagules). During 15 years old cultivation, cost of propagules is $11,90 \%$, tillage and rhizomes transplantation is $6,67 \%$, weeding and irrigation is $5,24 \%$, fertilization is $24,29 \%$ and harvesting is $51,43 \%$ in giant reed production (Pilu et al., 2012). It can be reduced the cost of propagules used by biotechnology-propagated plants, it can be less than 3000 euro ha $^{-1}$ depending on propagation technology (Corno et al. 2014, Antal, 2018). In Hungary, the consumption of the household sector (pellet, briquette etc.) is not significant, therefore biomass power plants can be greatest market of the plant. The prices of absolutely dry giant reed chops decreased to 8000 HUF from 16000 HUF in the last years (2014-2018). Based on our calculation, average direct cost of cultivation of giant reed is between $7200-7500$ HUF per dry tons in Hungary (without agricultural financial support), if are using 
biotechnologically propagated plants (Antal, 2018). The current low prices of energy and absence of the domestic processing industry are not contributed the profitable production.

Based on economic calculations carried out in similar years by Arundo Italia Ltd. (Italy), total cost of giant reed production exceeded the Hungarian data, but the costs of harvest and transportation are not significant, due to the proximity of the market outlets. The Italian company establishes giant reed plantations, particularly for biogas and bioethanol production with the suitable facilities. Currently, purpose of global giant reed production is biogas or bioethanol production, but other forms of its utilization were also reported.

\section{Utilization of giant reed compared to other biomass species}

The high heating value of giant reed is between 17-20 MJ $\mathrm{kg}^{-1}$, that is similar to other energy plants such as poplar, miscanthus, switchgrass etc. (Rabemanolontsoa \& Saka, 2013; Molari et al., 2014; Saikia et al., 2015). Giant reed has high ash and silicon content, such as switchgrass, which substances accumulate mainly in the leaves (Coulson \& Bridgwater, 2004; Monti et al., 2008). During combustion, this silicon-content with high potassium or chlorine elements may cause fouling or corrosion problem and rise amount of volatile particles (Monti et al., 2008). In experiment of Nassi o Di Nasso et al. (2010) confirmed that it can be improved the quality of biomass and heating value with the application of appropriate agronomy techniques (autumn-winter harvest and convenient fertilization).

In agronomy, environment and economic researches of Nassi o Di Nasso et al. (2010; 2011a; 2013a) and Angelini et al. (2009) compared the productivity and efficiency of giant reed production and utilization to miscanthus, short-rotation poplar or annual agricultural crops (sugar-beet, durum wheat, sorghum, sunflower). From the energy production of plants, energy input of cultivation of giant reed and miscanthus were close to equal per hectare (13 GJ), but in case of annual agricultural crops were more than $20 \mathrm{GJ}^{-1}$ and 3 yearly harvested poplar were $5 \mathrm{GJ} \mathrm{ha}^{-1}$. Maximum annual net energy yield can be reached with giant reed production $(\sim 600 \mathrm{GJ})$, the values of miscanthus $(\sim 450 \mathrm{GJ})$, poplar $(\sim 300 \mathrm{GJ})$ or agricultural crops $(\sim 110 \mathrm{GJ})$ are less. The annual emission of greenhouse gases can be calculated $1400 \mathrm{~kg} \mathrm{CO}_{2}$ equivalent in production of agricultural plants, and short-rotation poplar is less $(460 \mathrm{~kg})$ than giant reed or miscanthus $(800 \mathrm{~kg})$.

According to Schievano et al. (2012), giant reed has lower biogas productivity per dry matter than other traditional energy plants (corn, sorghum, triticale etc.). Due to its high biomass production, 7 170-11 $280 \mathrm{Nm}^{3} \mathrm{CH}_{4}$ production per hectare can be reached in one harvested process per year, so biomethane production of giant reed per unit area higher than other biomass plants. In the calculation of Ragaglini et al. (2014) with two moving per year can be rise with $20-35 \%$ bio-methane production per year. With one harvesting $9580 \mathrm{Nm}^{3} \mathrm{CH}_{4}$, two harvesting $11585-12981 \mathrm{Nm}^{3} \mathrm{CH}_{4}$ biogas yield measured per one year in same cultivation area. Based on Corno et al. (2014), 3 -year-old giant reed plantation with one harvesting an optimal period of a year (October) can be resulted much more biogas yield per hectare $\left(19440 \mathrm{Nm}^{3} \mathrm{CH}_{4}\right)$, than two harvesting in the same year and area (9930 $\mathrm{Nm}^{3} \mathrm{CH}_{4}$ per moving). Based on the calculation of Arundo Italia Ltd. (Italy), the unit biogas yield of giant reed $\left(16000 \mathrm{~m}^{3}\right)$ is one and half times exceeds the corns' $\left(11000 \mathrm{~m}^{3}\right)$, despite corn has higher biogas production per dry matter. Under 15 cultivation year, the total direct cost of giant reed production for biogas utilization is one third (11 850 euro) than corn (40 727 euro) per hectare (Corno et al., 2014; 2015; 2016). Furthermore, based on Di Girolamo et al. (2013) and Adani et al. (2010), with adequate pretreatment can be rise 12$60 \%$ the biogas yield from giant reed. The problem is the presence of volatile elements (especially silicon-containing compounds) which during digestion of the raw material can transform into silicon (Monti et al., 2008; Nassi o Di Nasso et al., 2010).

The processing method of bioethanol production of giant reed as a potential second generation lignocellulosic plants, is more complex and diverse from first generation bioethanol plants (cereals). In comparison with other bioethanol plants (cereals, sugar cane, miscanthus, sorghum etc.), giant reed produced generally 20 , even $50 \%$ higher bioethanol per hectare (11 000-15 000 litre), because of high biomass production and chemical components (Williams et al., 2008; Corno et al., 2014). In 2013, Mossi \& Ghisolfi Group (in Crescentino, Italy) was building a second gerenation bioethanol pilot plant with a capacity of 60 thousand tons per year supported by the European Union's Research and Innovation funding program (FP7-239204) with cooperation other consortium partner (Biochemtex, WIP Renewable Energy, Novozymes, ENEA, Agroconsulting, Italian Bio Products etc.). This pilot demonstration bioethanol plant can utilize 270000 dry tons plant material, such as agricultural residues and second generation bioethanol plants (miscanthus, sorghum, switchgrass and giant reed). Thanks to the developed Proesa technology, can be made efficiently the cellulose digestion and solved the utilization of lignin as electric energy (13 MW). Based on their economic profitability, annual total cost of bioethanol production from giant reed or agricultural residues (wheat straw) is less than 500 euro, which is cheaper than production from sorghum (600 euro) in case of capacity of 100000 tons material processing per year. Beside wheat straw, giant reed has been considered one of the most perspective raw materials. From giant reed can be produced 5 tons bioethanol per hectare with average 20 dry matter biomass yield and with cultivation of giant reed can reduce GHG emission with average 8 tons per year (Chiaramonti et al., 2013).

Due to the chemical structure of giant reed (cellulose, hemicellulose, lignin, protein etc.), it can be produced for biocompound of plastic (Fiore et al., 2014), green construction (Carneiro et al., 2016) and leaf protein concentrate (LPC) for feed ingredients (Molnár et al., 2015), not only bioenergy purposes. Based on own and Varga (2014) calculation, in case of recommended harvesting time (end of May), from 3-4 tons fresh matter giant reed biomass yield can be produced 190-300 $\mathrm{kg} \mathrm{ha}{ }^{-1}$ fresh leaf protein concentrate with $15-38 \%$ available crude protein content. The protein yield per hectare from giant reed is $58-74 \%$ less than measured from alfalfa, but there are no data from digestible or essential amino-acid content of LPC from giant reed or from other treated species. The protein yield is depending on harvesting time, chemical composition of ecotypes and applied technologies. During the process, large amounts of green fiber and brown juice are generated as byproducts, which can be used for varied purposes (as nutrition resources and medium for biological fermentation, as raw material for enzymes, biodegradable plastics, amino acids, vitamins, alcohol production etc.) (Bákonyi et al., 2018). Because of the high biomass yield of giant reed and growing demand for higher protein content products, it can be 
perspective to following researches in field of leaf protein concentrate production from giant reed.

\section{Discussion}

Based on above described numerous literature data and own field experiments, it can be determined some critical factors of giant reed production. Giant reed can be cultivated on different kind of soil and climate, but the cold is a limiting factor in production. For these reasons, can be concluded that in the production of the giant reed needs to utilize climate-adapted varieties or ecotypes to maintain the profitability. As phytoremediation plant can be cultivated also in marginal or heavy metal polluted lands. It cannot produce viable seeds and its rhizomes not creeping such as bamboo, but it can be invasive in wetland or coastal regions, so it is not suitable to establish a plantation next to the waterside. It can be propagated only by vegetative methods (rhizomes, stem cuttings, in vitro propagation) and the most of propagation methods are inefficient with higher propagation costs. As perennial plant, lesser number of cultivation elements of production resulted reducing in production costs, energy consumption and GHG emissions. Resulted that the direct production cost is lower compared to woody plants or one-year energy crops, because of significantly less fertilizer, pesticide and herbicide needs to produce high biomass yield. But the investment cost is higher, because of the establishment and propagules costs. Without irrigation it can be produced $20 \mathrm{DM}$ ton $\mathrm{ha}^{-1}$ in continental climate and 25-37 $\mathrm{DM}^{\mathrm{N}}$ ton $\mathrm{ha}^{-1}$ in a warmer climate, but high water content at harvesting (over $40 \%$ ), which increases the transport and processing costs. Although from giant reed can be produced for different kind of purposes (combustion, biogas, bioethanol and basic components for higher value added products such as bioplastic, fodder or other compounds), the processing cost of lignocellulose-based biomass can be higher. Despite of numerous environmental, economic and social benefits, due to the lack of manufacturing industry, cannot be declared that the todays the biomass-based technologies can be replaced or supplemented fossil energy-based technologies.

\section{Acknowledgements}

Supported by the ÚNKP-17-3 New National Excellence Program of the Ministry of Human Capacities.

\section{References}

Adani, F. - Papa, G. - Schievano, A. - Cardinale, G. D'Imporzano, G. - Tambone, F. (2010): Nanoscale structure of the cell wall protecting cellulose from enzyme attack. Environmental Science \& Technology, 45 (3): 1107-1113.

Alshaal, T. - Domokos-Szabolesy, É. - Márton, L. - Czakó, M. - Kátai, J. - Balogh, P. - Elhawat, N. - El-Ramady, H. Fári, M. (2013): Phytoremediation of bauxite-derived red mud by giant reed. Environmental Chemistry Letters, 11 (3): 295 302.

Alshaal, T. - Domokos-Szabolcsy, É. - Márton, L. - Czakó, M. - Kátai, J. - Balogh, P. - Elhawat, N. - El-Ramady, H. Gerőcs, A. - Fári, M. (2014): Restoring soil ecosystems and biomass production of Arundo donax L. under microbial communities-depleted soil. Bioenergy Research, 7 (1): 268 278.

Alshaal, T. - Elhawat, N. - Domokos-Szabolcsy, É. - Kátai, J. - Márton, L. - Czakó, M. - El-Ramady, H. - Fári, M. G. (2015): Giant reed (Arundo donax L.): a green technology for clean environment Phytoremediation (pp. 3-20): Springer.

Alshaal, T. (2013): Remediation and Restoring Marginal Lands with Biotechnologically Propagated Giant Reed (Arundo donax L.). Thesis of Doctoral (PhD) Dissertation. Debreceni Egyetem, Mezőgazdaság-, Élelmiszertudományi és Környezetgazdálkodási Kar.

Angelini, L. - Ceccarini, L. - Bonari, E. (2005): Biomass yield and energy balance of giant reed (Arundo donax L.) cropped in central Italy as related to different management practices. European Journal of Agronomy, 22 (4): 375-389.

Angelini, L. G. - Ceccarini, L. - o Di Nasso, N. N. - Bonari, E. (2009): Comparison of Arundo donax L. and Miscanthus $\mathrm{x}$ giganteus in a long-term field experiment in Central Italy: Analysis of productive characteristics and energy balance. Biomass and Bioenergy, 33 (4): 635-643.

Antal (2018): Zöld biomassza bioenergetikai célú hasznosításának nemzetközi és hazai helyzete, perspektívái (Global and national economic situation and prospects of green biomass utilization for bioenergy purposes). „Kihívások és tanulságok a menedzsment területén" Nemzetközi Tudományos Konferencia, 2018. március 8-9. Debreceni Egyetem, Müszaki Kar.

Antal, G. - Kurucz, E. - Fári, M. G. - Popp, J. (2014): Tissue culture and agamic propagation of winter-frost tolerant 'longicaulis' Arundo donax L. Environmental Engineering and Management Journal, 13 (11): 2709-2715.

Bákonyi, N. - O. Tóth I. - Kovács, Sz (2018): A lucerna savó, mint alternatív bioipari nyersanyag (Alfalfa brown juice, as alternative biobased raw material). XXIV. Növénynemesítési Tudományos Nap. 2018. március 6. Magyar Tudományos Akadémia, Budapest, 61.

Carneiro, P. - Jerónimo, A. - Silva, V. - Cartaxo, F. - Faria, P. (2016): Improving building technologies with a sustainable strategy. Procedia-Social and Behavioral Sciences, 216: 829840 .

Cavallaro, V. - Patanè, C. - Cosentino, S. L. - Di Silvestro, I. - Copani, V. (2014): Optimizing in vitro large scale production of giant reed (Arundo donax L.) by liquid medium culture. Biomass and Bioenergy, 69: 21-27.

Ceotto, E. - Castelli, F. - Moschella, A. - Diozzi, M. - Di Candilo, M. (2015): Cattle slurry fertilization to giant reed (Arundo donax L.): biomass yield and nitrogen use efficiency. BioEnergy Research, 8 (3): 1252-1262.

Ceotto, E. - Di Candilo, M. (2010): Shoot cuttings propagation of giant reed (Arundo donax L.) in water and moist soil: The path forward? Biomass and Bioenergy, 34 (11): 16141623.

Chiaramonti, D. - Giovanni, A. - Janssen, R. - Mergner, R. e. (2013): Lignocellulosic Ethanol Process and Demonstration: Handbook Part I. Munich, Germany: WIP Renewable Energies. 1140.http://www.biolyfe.eu/images/stories/downloads/BIOLY FE\%20Handbook\%20Part\%20I.pdf

Christou, M. - Mardikis, M. - Alexopoulou, E. - Cosentino, S. - Copani, V. - Sanzone, E. (2003): Environmental studies 
on Arundo donax. Proceedings of the 8th International Conference on Environmental Science and Technology, vol. B. $102-110$

Corno, L. - Lonati, S. - Riva, C. - Pilu, R. - Adani, F. (2016): Giant cane (Arundo donax L.) can substitute traditional energy crops in producing energy by anaerobic digestion, reducing surface area and costs: A full-scale approach. Bioresource Technology, 218: 826-832.

Corno, L. - Pilu, R. - Adani, F. (2014): Arundo donax L.: a non-food crop for bioenergy and bio-compound production. Biotechnology Advances, 32 (8): 1535-1549.

Corno, L. - Pilu, R. - Tambone, F. - Scaglia, B. - Adani, F. (2015): New energy crop giant cane (Arundo donax L.) can substitute traditional energy crops increasing biogas yield and reducing costs. Bioresource Technology, 191: 197-204.

Cosentino, S. L. - Copani, V. - D'Agosta, G. M. - Sanzone, E. - Mantineo, M. (2006): First results on evaluation of Arundo donax L. clones collected in Southern Italy. Industrial Crops and Products, 23 (2): 212-222.

Cosentino, S. L. - Copani, V. - Patanè, C. - Mantineo, M. D'Agosta, G. M. (2008): Agronomic, energetic and environmental aspects of biomass energy crops suitable for Italian environments. Italian Journal of Agronomy, 3 (2): 8196.

Coulson, M. - Bridgwater, A. (2004): Fast pyrolysis of annually harvested crops for bioenergy applications. Proceedings of the 2nd World Conference on Biomass. 1098

Csete, S. (2008a): Lágyszárú energianövények és felhasználásuk szilárd tüzelésű energetikai rendszerekben hazai és nemzetközi körkép (Herbaceous energy crops and their utilization in solid-fired energetic systems: domestic and international overview). Biomassza Konferencia, Sopron, 5th March, 2008

Csete, S. (2008b): Lágyszárú energianövények és felhasználhatóságuk szilárd tüzelésű energetikai rendszerekben II. (Herbaceous energy crops and their utilization in solid-fired energetic systems II.). Bioenergia, 3 (3): 19-24.

Csete, S. (2008c): Lágyszárú energianövények és felhasználhatóságuk szilárd tüzelésü energetikai rendszerekben III. (Herbaceous energy crops and their utilization in solid-fired energetic systems III.). Bioenergia, 3 (4): 34-40.

Di Girolamo, G. - Grigatti, M. - Barbanti, L. - Angelidaki, I. (2013): Effects of hydrothermal pre-treatments on Giant reed (Arundo donax) methane yield. Bioresource Technology, 147: 152-159.

Domokos-Szabolcsy, E. - Alladalla, N. - Alshaal, T. - Sztrik, A. - Márton, L. - El-Ramady, H. (2014): In vitro comparative study of two Arundo donax L. ecotypes' selenium tolerance. Int J Hortic Sci, 20 (3-4): 119-122.

Dragoni, F. - o Di Nasso, N. N. - Tozzini, C. - Bonari, E. Ragaglini, G. (2015): Aboveground yield and biomass quality of giant reed (Arundo donax L.) as affected by harvest time and frequency. BioEnergy Research, 8 (3): 1321-1331.

Dragoni, F. - o Di Nasso, N. N. - Tozzini, C. - Bonari, E. Ragaglini, G. (2016): Nutrient concentrations and uptakes in giant reed (Arundo donax L.) as affected by harvest time and frequency. BioEnergy Research, 9 (2): 671-681.

Elhawat, N. - Alshaal, T. - Domokos-Szabolcsy, É. - ElRamady, H. - Antal, G. - Márton, L. - Czakó, M. - Balogh,
P. - Fári, M. (2015): Copper uptake efficiency and its distribution within bioenergy grass giant reed. Bulletin of Environmental Contamination and Toxicology, 95 (4): 452458.

Elhawat, N. - Alshaal, T. - Domokos-Szabolcsy, É. - ElRamady, H. - Márton, L. - Czakó, M. - Kátai, J. - Balogh, P. - Sztrik, A. - Molnár, M. (2014): Phytoaccumulation potentials of two biotechnologically propagated ecotypes of Arundo donax in copper-contaminated synthetic wastewater. Environmental Science and Pollution Research, 21 (12): 77737780 .

Elhawat, N. - Alshaal, T. - Kratz, S. - Domokos-Szabolcsy, É. - El-Ramady, H. - Prokisch, J. - Eszenyi, P. - Sztrik, A. Babka, B. - Fári, M. (2013a): Ecotoxicology of copper in horticultural soils: a review. International Journal of Horticultural Science, 19 (1-2): 7-18.

Elhawat, N. - Domokos-Szabolcsy, É. - Alshaal, T. Molnár, M. - Antal, G. - Márton, L. - Fári, M. G. (2013b): Szomatikus embrió eredetű olasznád (Arundo donax L.) klaszterek in vitro sótürése két ökotípus összehasonlításával (In vitro salt tolerance of two giant reed (Arundo donax L.) ecotype derived somatic embryogenesis). XIX. Növénynemesítési Tudományos Napok, 7th March, 2013, Keszthely. Keszthely

El-Ramady, H. - Abdalla, N. - Alshaal, T. - El-Henawy, A. Salah, E.-D. F. - Shams, M. S. - Shalaby, T. - Bayoumi, Y. Elhawat, N. - Shehata, S. (2015): Selenium and its role in higher plants Pollutants in Buildings, Water and Living Organisms (pp. 235-296): Springer.

Fári M. G., Antal G., Kurucz E., Domokosné Szabolcsy É. (2014): Biogenerációs növények kutatása a Debreceni Egyetemen és a magyar agrár-biotechnológiai innováció néhány kitörési pontja (Researches of biogeneration plants in University of Debrecen and innovation development directions of Hungarian Agricultural Biotechnology). In: Sustainable energy by optimal integration of renewable energy sources (DEnzero). Akadémiai Kiadó, ISBN: 978963059540 7, 237 268.

Fiore, V. - Botta, L. - Scaffaro, R. - Valenza, A. - Pirrotta, A. (2014): PLA based biocomposites reinforced with Arundo donax fillers. Composites Science and Technology, 105, pp. 110-117. http://dx.doi.org/10.1016/j.compscitech.2014.10.005

Fogarassy, C. (2001): Energianövények a szántóföldön (Energy crops in agricultural land): Szent István Egyetem GTK Európai Tanulmányok Intézete. ISBN: 9639256471. 1-144.

Gyulai, I. (2009): A biomassza dilemma (Biomass issues). Magyar Természetvédők Szövetsége (4): 1-116.

IEA (2017): Key world energy statistics. International Energy Agency,

https://www.iea.org/publications/freepublications/publication/ KeyWorld2017.pdf, 97 p.

Krickl, M. (1946): Zur Frage der Züchtung einer winterharten Arundo donax L. Theoretical and Applied Genetics, 17 (3): $67-$ 69.

Lange, L. - Lindedam, J. (2016): The Fundamentals of Bioeconomy, The Biobased Society. United Federation of Danish Workers 3F, Technical University of Denmark, Copenhagen,

http://orbit.dtu.dk/ws/files/140638164/Lange_L_Lindedam_J_ 
2016_The_Fundamentals_Of_Bioeconomy_The_Biobased_So ciety..pdf, 20 p.

Mantineo, M. - D’agosta, G. - Copani, V. - Patanè, C. Cosentino, S. (2009): Biomass yield and energy balance of three perennial crops for energy use in the semi-arid Mediterranean environment. Field Crops Research, 114 (2): 204-213.

Mariani, C. - Cabrini, R. - Danin, A. - Piffanelli, P. Fricano, A. - Gomarasca, S. - Dicandilo, M. - Grassi, F. Soave, C. (2010): Origin, diffusion and reproduction of the giant reed (Arundo donax L.): a promising weedy energy crop. Annals of Applied Biology, 157 (2): 191-202.

Márton, L. - Czakó, M. (2002a): Selecting an explant of living tissue from the plant and cultivating the tissue on a primary medium to produce totipotent tissue. USA Patent No. US 6821782 B2. 05.02.2002. https://www.google.hu/patents/U S6821782?dq=US+6821782+B2\&hl=hu\&sa=X \&ved=0ahUK Ewjw4oqB0MPPAhUFj iwKHWbXAe QQ6AEIHDAA

Márton, L. - Czakó, M. (2002b): Sustained totipotent regenerable tissue culture of Arundo donax (giant reed) and totipotent tissue and plants produced therefrom. European Patent Register, Patent No. WO 2002063023 A2. 05.02.2002. https://www.google.hu/patents/WO2002063023A2?cl=en\&dq= $\mathrm{WO}+2002063023+\mathrm{A} 2 \& \mathrm{hl}=\mathrm{hu} \& \mathrm{sa}=\mathrm{X} \& \mathrm{ved}=0 \mathrm{ahUKEwiRoJ} 2 \mathrm{j} 0$ MPPAhVJkCwKHW07Aa8Q6AEIHDAA

Márton, L. - Czakó, M. (2007a): Method for micropropagation of monocots based on sustained totipotent cell cultures. European Patent Register. https://www.google.hu/patents/EP2150100B1?cl=en\&dq=EP+ 2150100+B1\&hl=hu\&sa=X\&ved=0ahUKEwi6k93Z0MPPAh WJFiwKHXTsCr0Q6AEIHDAA

Márton, L. - Czakó, M. (2007b): Propagating Arundo species in nutrient broth and on teriary medium containing auxin and cytokinin. USA Patent No. US 7863046 B2. 07.05.2007. https://www.google.hu/patents/US7863046?dq=US+7863046+ B2\&hl=hu\&sa=X\&ved=0ahUKEwjW04fv0MPPAhVCjywKH RApCu0Q6AEIHDAA

Mlinarics, E. - Dergez, Á. - Blaskó, L. - Bordás, D. - Zsigrai, G. - Kiss, I. - Szabó, S. (2009): Possibilities of plant production for biorefinery on a soil contaminated with heavy metals, Analele Universităţii din Oradea, Fascicula Protecţia Mediului. 746-753

Molari, G. - Milani, M. - Toscano, A. - Borin, M. - Taglioli, G. - Villani, G. - Zema, D. A. (2014): Energy characterisation of herbaceous biomasses irrigated with marginal waters. Biomass and Bioenergy, 70: 392-399.

Molnár, M. - Antal, G. - Varga, Á. - Deme, A. - Pócsi, I. Fári, M. (2015): Növényi levélfehérje koncentrátum (LPC) költséghatékonyabb előállítása és a melléktermékek alkalmazási lehetöségei. (Cost-effective production of leaf protein concentrate (LPC) and application possibilities of byproducts). XXI. Növénynemesítési Tudományos Napok, Magyar Tudományos Akadémia, 2018. március 11-12. Agrártudományi Kutatóközpont Martonvásár, 105.

Monti, A. - Di Virgilio, N. - Venturi, G. (2008): Mineral composition and ash content of six major energy crops. Biomass and Bioenergy, 32 (3): 216-223.

Nassi o Di Nasso, N. - Angelini, L. - Bonari, E. (2010): Influence of fertilisation and harvest time on fuel quality of giant reed (Arundo donax L.) in central Italy. European Journal of Agronomy, 32 (3): 219-227.

Nassi o Di Nasso, N. - Roncucci, N. - Bonari, E. (2013a): Giant reed (Arundo donax L.) as energy crop in Central Italy: a review. Italian Journal of Agronomy, 8 (1S): 10-17.

Nassi o Di Nasso, N. - Roncucci, N. - Bonari, E. (2013b): Seasonal dynamics of aboveground and belowground biomass and nutrient accumulation and remobilization in giant reed (Arundo donax L.): a three-year study on marginal land. BioEnergy Research, 6 (2): 725-736.

Nassi o Di Nasso, N. - Roncucci, N. - Triana, F. - Tozzini, C. - Bonari, E. (2011a): Productivity of giant reed (Arundo donax L.) and miscanthus (Miscanthus x giganteus Greef et Deuter) as energy crops: growth analysis. Italian Journal of Agronomy, 6 (3): 22 .

Nassi o Di Nasso, N. - Roncucci, N. - Triana, F. - Tozzini, C. - Bonari, E. (2011b): Seasonal nutrient dynamics and biomass quality of giant reed (Arundo donax L.) and miscanthus (Miscanthus $x$ giganteus Greef et Deuter) as energy crops. Italian Journal of Agronomy, 6 (3): 24.

Neto, C. P. - Seca, A. - Nunes, A. - Coimbra, M. Domingues, F. - Evtuguin, D. - Silvestre, A. - Cavaleiro, J. (1997): Variations in chemical composition and structure of macromolecular components in different morphological regions and maturity stages of Arundo donax. Industrial Crops and Products, 6 (1): 51-58.

Pilu, R. - Badone, F. C. - Michela, L. (2012): Giant reed (Arundo donax L.): A weed plant or a promising energy crop? African Journal of Biotechnology, 11 (38): 9163-9174.

Pompeiano, A. - Vita, F. - Miele, S. - Guglielminetti, L. (2015): Freeze tolerance and physiological changes during cold acclimation of giant reed [Arundo donax (L.)]. Grass and Forage Science, 70 (1): 168-175.

Popp, J. - Fári M. G. (szerk.) (2016): Biotechnológia-anno 1920-1938 és ma, Ereky Károly programja a fehérjeprobléma megoldásáról és napjaink feladatai (Biotechnology-anno 19201938 and today, Karoly Ereky's research and development program of solutions of the protein problem and the tasks of today). Molnár M. - Fári M. G. - Antal G. - Domokosné Szabolcsy É. - Harangi-Rákos M. - Kurucz E. - Kralovánszky U. P.† - Lisztes-Szabó Zs. - Pető K. - Szakály Z. - Veres Sz. Popp J. (2016): 436 p. Szaktudás Kiadó Ház, ISBN:978-6155224-67-6

Rabemanolontsoa, H. - Saka, S. (2013): Comparative study on chemical composition of various biomass species. RSC Advances, 3 (12): 3946-3956.

Ragaglini, G. - Dragoni, F. - Simone, M. - Bonari, E. (2014): Suitability of giant reed (Arundo donax L.) for anaerobic digestion: effect of harvest time and frequency on the biomethane yield potential. Bioresource Technology, 152: 107 115 .

Roncucci, N. - o Di Nasso, N. N. - Triana, F. - Taccini, F. Tozzini, C. - Bonari, E. (2012): Biomass partitioning in a giant reed (Arundo donax L.) crop: A three-year study, https://www.researchgate.net/profile/Neri_Roncucci/publicatio n/235989465_Biomass_Partitioning_in_a_Giant_Reed_Arundo _donax_L_crop_a_threeyear_study/links/0deec5154373 d06bcd 000000/Biomass-Partitioning-in-a-Giant-Reed-Arundo-donaxL-crop-a-three-year-study.pdf. 
Saikia, R. - Chutia, R. S. - Kataki, R. - Pant, K. K. (2015):

Perennial grass (Arundo donax L.) as a feedstock for thermochemical conversion to energy and materials. Bioresource Technology, 188: 265-272.

Schievano, A. - D'Imporzano, G. - Corno, L. - Adani, F. Cerino Badone, F. - Pilu, S. (2012): Più biogas a costi inferiori con arundo o doppia coltura. L'Informatore Agrario, 25: $21-25$.

Shatalov, A. A. - Pereira, H. (2002a): Carbohydrate behaviour of Arundo donax L. in ethanol-alkali medium of variable composition during organosolv delignification. Carbohydrate Polymers, 49 (3): 331-336.

Shatalov, A. A. - Pereira, H. (2002b): Influence of stem morphology on pulp and paper properties of Arundo donax L. reed. Industrial Crops and Products, 15 (1): 77-83.

Simon, L. - Szabó, B. - Szabó, M. - Vincze, G. - Varga, C. Uri, Z. - Koncz, J. (2012): Effect of various soil amendments on the mineral nutrition of Salix viminalis and Arundo donax energy crops. European Chemical Bulletin, 2 (1): 18-21.
Varga, Á. (2014): Levélfehérje koncentrátum előállítás MWC technológiára alapozva alternatív növényfajok esetében (Leaf protein concentrate from alternative species based on MWC technology). Debreceni Egyetem, MezőgazdaságÉlelmiszertudományi és Környezetgazdálkodási Kar, 49 p.

Ververis, C. - Georghiou, K. - Christodoulakis, N. - Santas, P. - Santas, R. (2004): Fiber dimensions, lignin and cellulose content of various plant materials and their suitability for paper production. Industrial Crops and Products, 19 (3): 245-254.

WBA (2017): WBA Global Bioenergy Statistics 2017. World Bioenergy Association, http://worldbioenergy.org/uploads/ WBA\%20GBS\%202017_hq.pdf, 80 p.

Williams, C. - Biswas, T. - Schrale, G. - Virtue, J. Heading, S. (2008): Use of saline land and wastewater for growing a potential biofuel crop (Arundo donax L.). Irrigation Australia 2008 Conference. http://irrigation.org.au/documents/ publicationsresources/conference_papers_2008/200508_Strea m3_CMJWilliams.pdf 